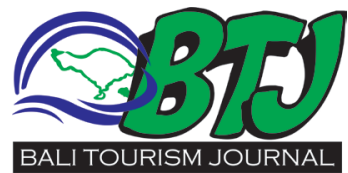

\section{Historical Temple of Dalem Balingkang: A Balinese Chinese Acculturation}

*Bali Karma Construction agungwicaksana12@gmail.com

Received: 2021-02-25

Accepted: 2021-03-22

Published: 2021-04-02

\author{
Ida Bagus Agung Wicaksana*
}

\section{ABSTRACT}

Dalem Balingkang temple depicts distinctive ornaments and interiors that resemble Chinese ambiance. It could be seen from the dominance of red and golden paints, architectural finishing, and Chinese shrine existence inside the main temple. The temple has been acknowledged as representing Balinese and Chinese customs acculturation that has existed for centuries. It was a palace for King Sri Haji Jaya Pangus who according to Purana Dalem Balingkang, reigned Bali in 1053 Isaka/1131 AD. However, due to some circumstances, the castle was left abandoned. Then a King from Pejeng, I Dewa Mayun Sudha, reconstructed the palace ruin into a temple to praise the late King and Queen of Dalem Balingkang. King Sri Haji Jaya Pangus's marriage with the daughter of Chinese trader Kang Ching We became a significant momentum of the acculturation of two cultures, Balinese and Chinese. As upper-class citizens, their marriage set a new standard in society. Gradually some foreign habits and customs were absorbed in local daily life. It can be seen in various aspects of their life, from ritual, economic, religion, social, architecture, art and culture. Further, Balinese Chinese culture's acculturation also occurred throughout Bali's region and existed up to the moment.

Keywords: Dalem Balingkang Temple, Balinese, Chinese, Acculturation

Cite This Article: Wicaksana, I.B.A. 2021. Historical Temple of Dalem Balingkang: A Balinese Chinese Acculturation. Bali Tourism Journal 5(1): 5-9. D0l: 10.36675/btj.v5i1.51

\section{INTRODUCTION}

Dalem Balingkang temple depicts distinctive ornaments and interiors that resemble Chinese ambiance. It could be seen from the dominance of red and golden paints, architectural finishing, and Chinese shrine existence inside the main temple. The temple has been acknowledged as representing Balinese and Chinese customs acculturation that has existed for centuries. The historical record mentioned Chinese traders had been aware of Bali island since the $7^{\text {th }}$ century. They called the island as $\mathrm{Dva}-\mathrm{Pa}$ Tan. They accidentally found the island after being stranded on Pegonjongan beach in the Singaraja area. From that point, they continued their exploration to the southern part of Kintamani and reached the magnificent kingdom of Bali Dwipa on Mount Panarajon (Penulisan Mountain). ${ }^{1}$

Further, they reached the Mount Batur area. According to the Chinese trader historical records, The Balinese were uninterested in the world of trade. They lived in an agricultural society and devoted their lives to serve their king. ${ }^{2}$ Warmly greeted by the king, the entourage decided to reside in villages later known as Songan and Pinggan. Pinggan Village is located at an altitude of 1,300 meters above sea level with a backdrop of Mount Batur and Mount Penulisan. An interesting fact to be known that the Songan and nearby Lampu Villages' name was derived from the words of Song-Ahn and Lam Pho clans who lived there. ${ }^{3}$

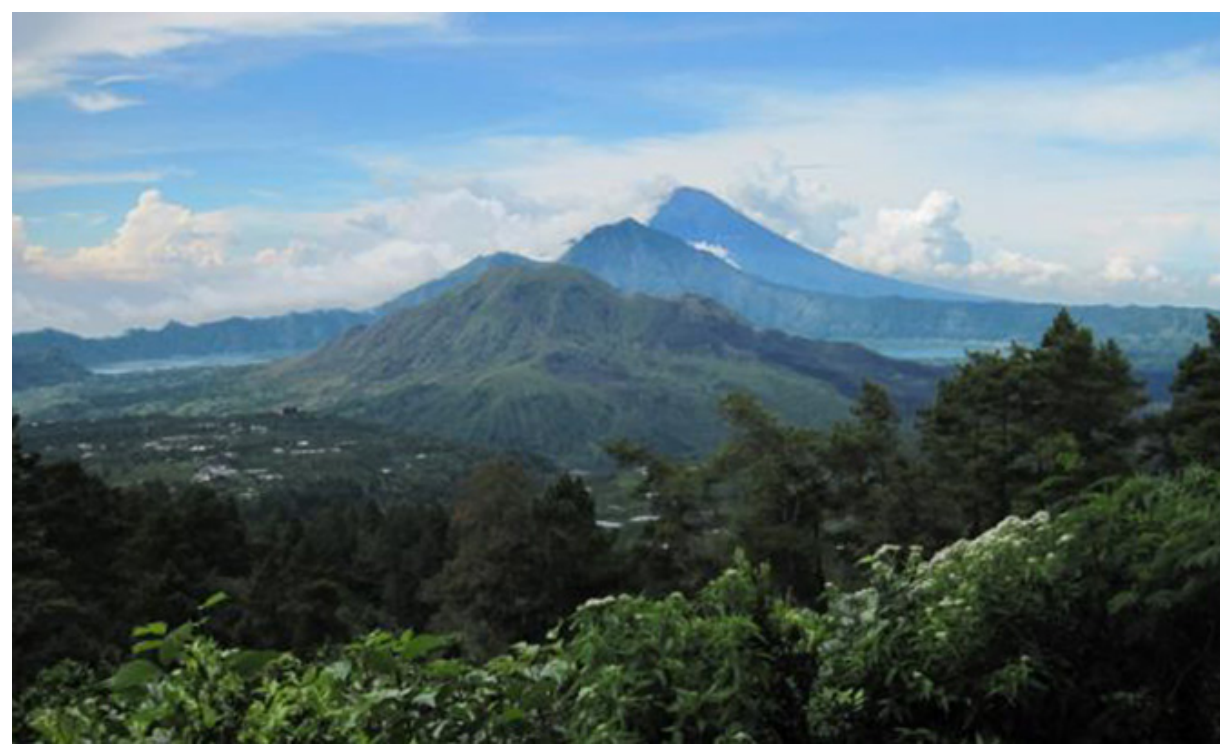

Figure 1. Mount Panarajon (Penulisan). The Chinese traders continued their exploration of Kintamani's southern part and reached the magnificent kingdom of Bali Dwipa on Mount Panarajon (Penulisan Mountain). ${ }^{4}$
Previously, the temple of Dalem Balingkang was a palace for King Sri Haji Jaya Pangus. Purana Dalem Balingkang, the temple's historical record, mentioned around the year 1053 Isaka/1131 AD, the king who occupied the royal throne in Bali 
Dwipa was a descendant of the last king. He was Sri Haji Jaya Pangus, who reigned in the kingdom of Bali Dwipa. Previously, he ruled his kingdom in Kuta Dalem Jong Les at Mount Panarajon (Penulisan). However, the castle was destroyed by catastrophe, forcing the king and his men to refuge. They started a new life in Pinggan Area. The Sukawana Inscription states that a rainstorm hit Sukawana Village, and the Jaya Pangus Palace in Puncak Penulisan was destroyed. ${ }^{5}$ In Pinggan, they built a new castle called Dalem Balingkang. In the record of "Village of Les Penuktukan, Tejakula, Buleleng," the site served as a temple and as the Palace of the King of Ancient Bali. The record was issued by King Jaya Kasunu around the $11^{\text {th }}$ century. He was the ancestor of King Jaya Pangus Harkajalancana. ${ }^{6}$

Further, the temple's historical record explained the meaning of the holy place name. Dalem Balingkang derived from the words Dalem, Bali, Ing, and Kang. The word 'Dalem' is taken from the area's name Kuta Dalem Jong Les. 'Bali' is taken from the kingdom's name, whereas 'Kang' is taken from the Queen's surname, Kang Ching We. ${ }^{7,8}$ The record described King Sri Haji Jaya Pangus and his two consorts: Sri Prameswari Induja Ketana on the right and Sri Mahadewi Sasangkaja Cihna (Kang Ching We) the left brought peace, glory and prosperity to the land of Bali Dwipa. Since then, King Sri Haji Jaya Pangus was known as King Dalem Balingkang, or in local tongue called as Prabu Dalem Balingkang. Years after King Dalem Balingkang's death, the text mentioned that the king's descendant left the castle and moved the kingdom into Batanyar (Bedahulu) area. The citadel was abandoned for a long time. It was finally rebuilt into the temple after the King of Pejeng, I Dewa Mayun Sudha, received spiritual guidance. The unknown voice requested him to find the castle ruin of Dalem Balingkang. He and his people tracked the ruin's location and reconstructed the forgotten site into a holy site. Today, the word Dalem Balingkang may refer to the temple's name, area, and the late King Sri Haju Jaya Pangus. The temple itself becomes a holy place to praise entities such as Ida Bhatara Dalem Balingkang (King Sri Haji Jaya Pangus), The Goddess of Lake Batur (Dewi Danu), and Ratu Ayu Mas Subandar (Queen Kang Ching we).

\section{LOCAL'S MYTH AND BARONG LANDUNG LEGEND}

Balinese societies have believed several myths until today regarding the tale of King Sri Haji Jaya Pangus and Dalem Balingkang temple. However, only two stories gained massive attention in Balinese society. First, the legend that based on a folktale that the elders continuously tell. Second, the King Jaya Pangus story in literary work called Kekawin (Hymn) Barong Landung.

Based on the myth developed in the community around Dalem Balingkang temple, it was said long ago that there was a king named Sri Haji Jaya Pangus. He had a Queen named Bhatari Mandul, or infertile Queen. Due to the Queen's condition, the king could not have a child. However, King Sri Jaya Pangus was eager to have a son. Thus his son would continue to rule the kingdom. When he was walking in the market, he met a beautiful-looking woman, a Chinese merchant's daughter. Captivated by the lady's appearance, he wished to marry her secretly-neither by proper ceremony nor by his wife's approval. The king's secret marriage infuriated the old God. The king was expelled from his palace in Panarajon since he broke the custom that obliged a king should be married with a proper Yadnya ceremony.

Sri Haji Jaya Pangus, accompanied by his two consorts, descended from Panarajon hill through the forest to the northeast during heavy rains and tornadoes. They tirelessly carried on their journey down the hills until they reached Mount Lebih. There he rested and worshiped the gods, asking for guidance and seeking His protection. He received a word from the Gods to continue his journey until the rain and wind stopped. When the rain and wind subsided, he was ordered to put up a sign and build a palace called Kuta Dalem Jong Les.

Remembering the word of the gods, he continued his journey down the hill of Panarajon accompanied by his two consorts to Dharma Anyar, a place of hermitage for saints, either Mpu, Maha Rsi, or others. When he arrived at Dharma

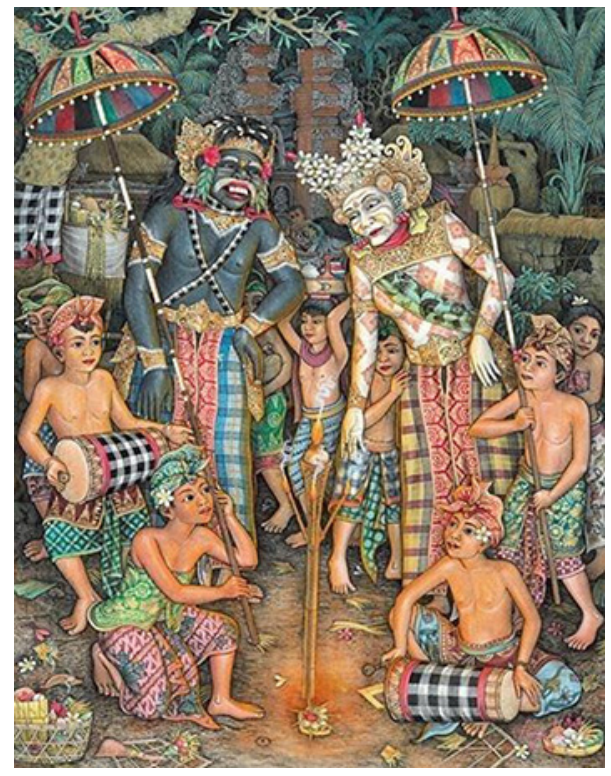

Figure 2. Artwork of Barong Landung. ${ }^{10}$

Anyar, the rain and wind began to subside. Finally, at Dharma Anyar, he built a palace known as Balingkang. There he was accompanied by the Senapati Kuturan, royal officials, and his two consorts.

Sri Haji Jaya Pangus' marriage to a Chinese princess, who was later called Dewi Danu. She gave birth to a son named Mayadanawa. Mayadanawa later would be known by the title Dalem Bedahulu, A notorious king of Pejeng. He met his demise after Gajah Mada, a great commander from the Majapahit empire, defeated him. Over time, the former Sri Haji Jaya Pangus palace in Balingkang was used to worship the soul of Sri Haji Jaya Pangus and his two consorts. They had been purified through a Yadnya ceremony. Until now it is known as Pura Dalem Balingkang. ${ }^{9}$

A literary work called Barong Landung hymn describes a different storyline compared to the historical record written in Purana Dalem Balingkang or on society myth. The hymn told King Jaya Pangus, who fell in love with the daughter of a Chinese trader. The lady's name was Kang Ching we. However, the king's wishes were against the old custom. Mpu Siwa Gandhu, the king's advisor, challenged the king's decision but only ignored in the end. Then, he cursed the kingdom at mount Panarajon to be destroyed by catastrophe. The newlywed king fled with his Queen 
and people to an area called Pinggan. There, they started a new kingdom called Dalem Balingkang.

Unfortunately, after years of marriage, the couple did not have any children. The restless king requested permission from his wife to seek an answer. He decided to meditate at Mount Batur, asking for God's blessing; thus, they might be someday able to bear a child. The Queen granted her permission for King Jaya Pangus to go for meditation. Then he left the kingdom to meditate at the Mount Batur area.

After few months at mount Batur for meditation, the king met a beautiful lady at the lakeside of Batur. She was Dewi Danu, the goddess of Lake Batur. Jaya Pangus was unaware of the lady's background and succumbed to the goddess's beauty. The king decided to approach the goddess to know more about her. Blinded by lust, the king said that he was an unmarried man to Dewi Danu. The goddess welcomed the king's feeling. Together, they decided to marry in secret and live in the forest near Batur lake.

The worried Queen Kang Ching We finally left the castle to find her husband

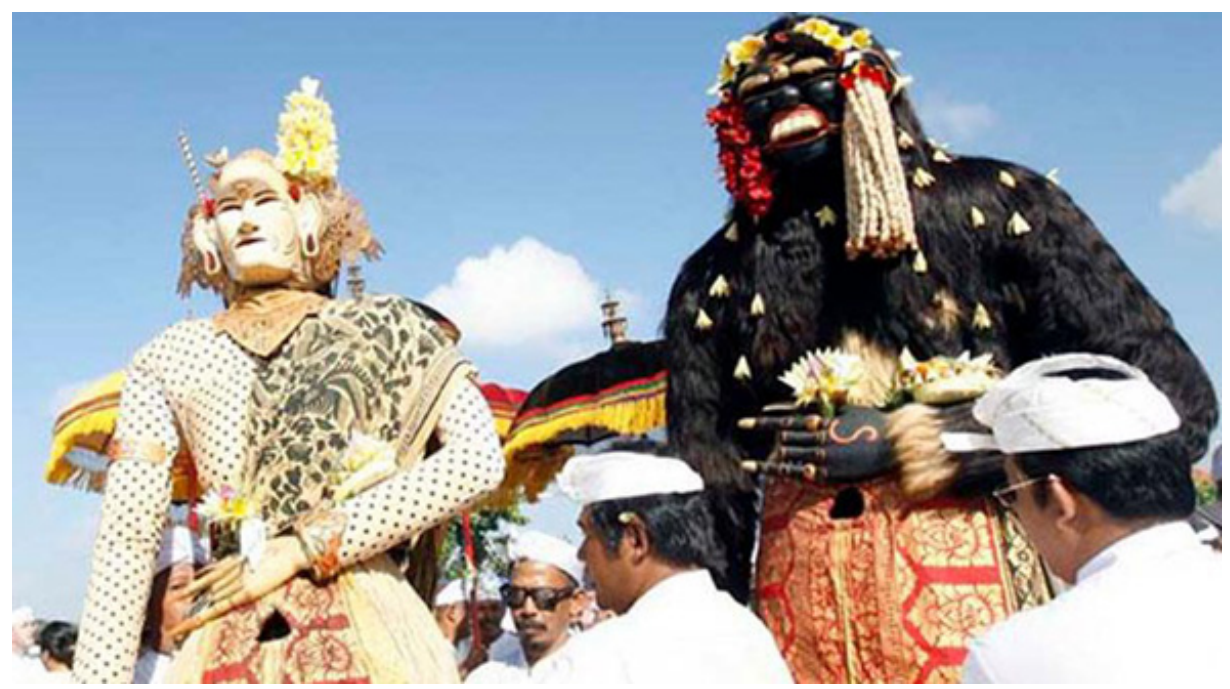

Figure 3. From the ashes of the deceased King Jaya Pangus and Queen Kang, she reanimated them in the form of two giant idols known as Barong landung. ${ }^{11}$

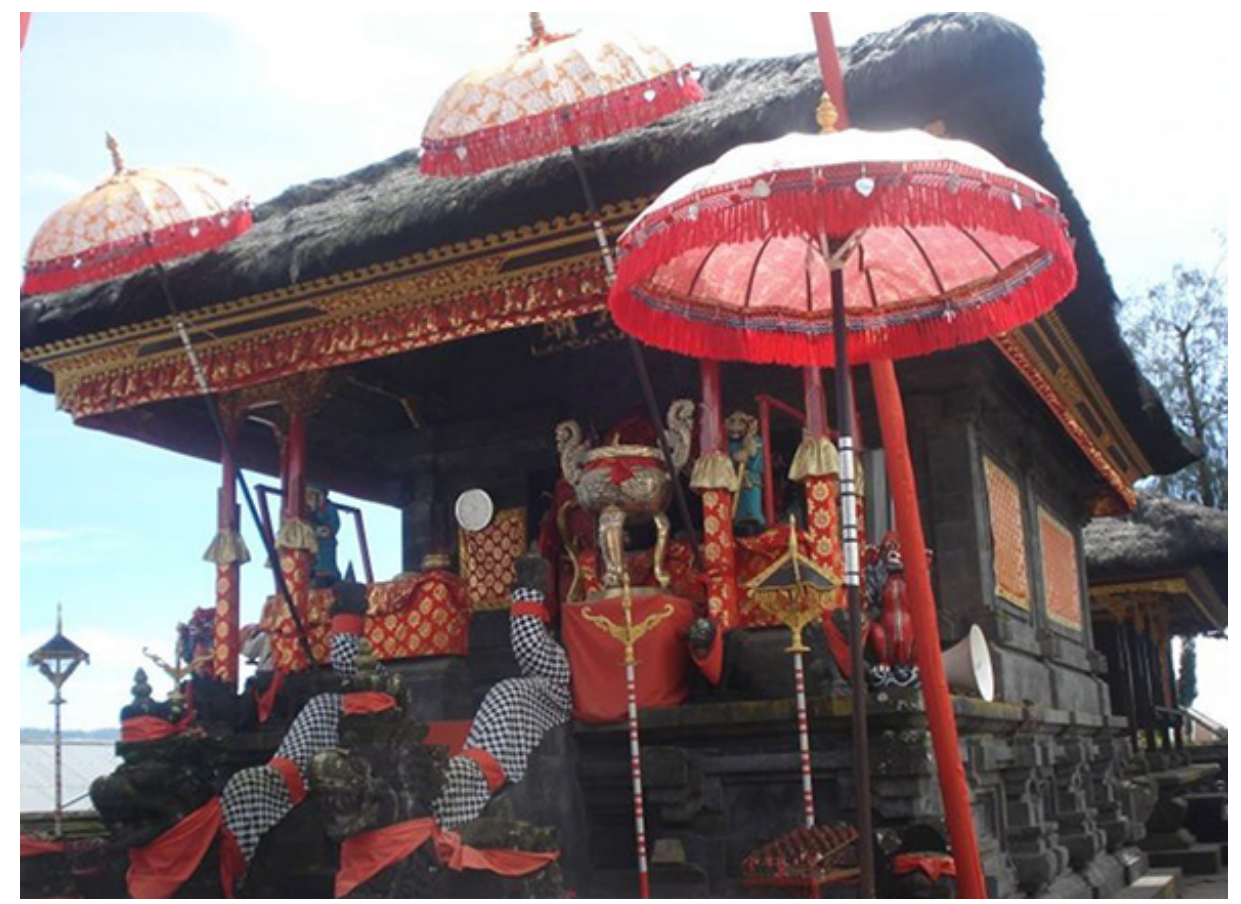

Figure 4. The Shrine of Ratu Ayu Mas Subandar. ${ }^{12}$ since he was gone for a long time. Their people kept asking about the king's whereabouts, but the Queen could not know where the king was. They explored the Batur area for days, only to find the king with his new wife in a small hut. Queen Kang was deeply infuriated.

She blindly attacked Dewi Danu and insulted her as low life thief. The goddess was angry. She was unaware of the reason why the foreign lady was mad at her. In confusion, she asked her husband for an explanation. With a trembling voice, Sri Haji Jaya Pangus admitted that he was a married man and a king of Dalem Balingkang. He apologized for his mistake of not telling the truth to Dewi Danu. However, the goddess was upset, for she was betrayed.

Consumed by anger, The goddess of lake Batur showed her spiritual power. She instantly annihilated King Sri Haji Jaya Pangus and Queen Kang Ching We to smithereens before the Queen's envoys. The people screamed, witnessing both their King and Queen met their end tragically. They asked for Dewi Danu's mercy; without any leader, they would be unable to live their life. The Dalem Balingkang's people sincerity moved the goddess. From the ashes of the deceased King Jaya Pangus and Queen Kang, she reanimated them in the form of two giant idols known as Barong landung. The first idol is a black, hairy giant figure, and the other is white, pale skin, tall, smiling lady. The black hairy giant has squinted eyes, full lips, bucktoothed, and black straight long hair. Then the tall white lady has squinted eyes, a wrinkled face, long ears, and updo white hair. The goddess advised the people to take those idols back to the castle and treat them as their late rulers. ${ }^{11}$ Although there were discrepancies in the history timeline, each version has fundamental similarities. Those stories illustrated that there were strong relationships between the Balinese and the Chinese communities since that time.

\section{ACCULTURATION OF TWO CULTURES}

From the Balinese Hindu's perspective, there were interactions between followers of Hindu and Buddhist religions. Mpu Siwa Gandhu and Kang Ching We's 


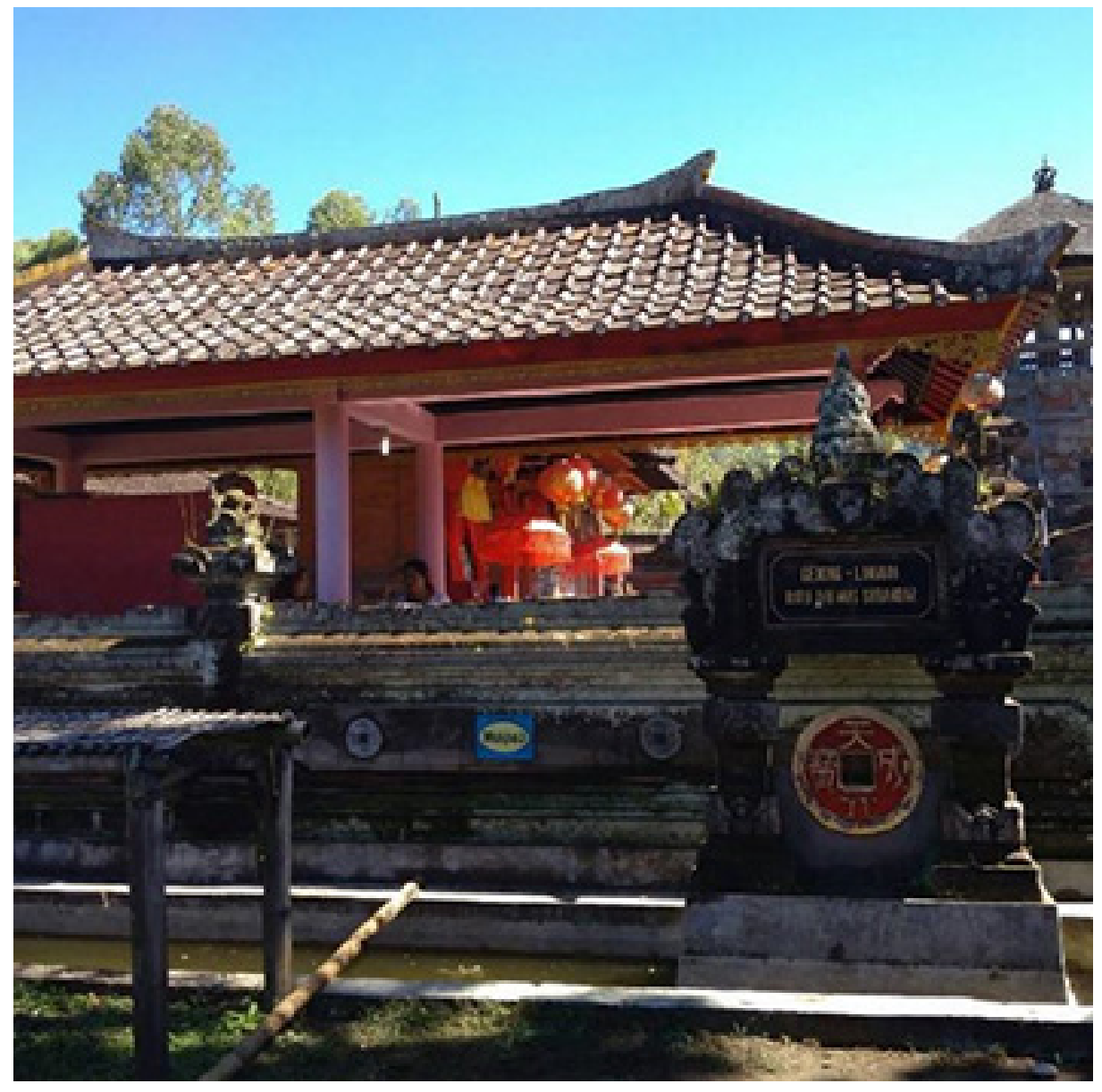

Figure 5. The shrine of Ratu Ayu Mas Subandar sits inside the main temple on the northeast side. It is easily recognized from its Kupang nameplate. ${ }^{14}$

existence in the kingdom represented the Hindu Shiva-buddha concept in King Jaya Pangus's reign. Furthermore, Cultural unification can be seen in the marriage of Sri Haji Jaya Pangus, from Bali Mula ancestry, with Kang Ching We, who came from Chinese ancestry. These two notable events reflected the implementation of the purusa (masculine) and pradana (feminine), Shiva-Buddha concept, in a higher society level. ${ }^{11}$

From an architectural perspective, the Dalem Balingkang temple encompasses various Balinese architecture from different periods. It colors the temple's construction, ranging from Bali Mula and Bali Aga architectures (10 ${ }^{\text {th }}$ centuries), Majapahit invasion (1343 AD), Danghyang Nirarta Visit (in 1489 AD during the reign of Dalem Waturenggong), and Modern Bali (after Indonesia independence, from 1945 up to the moment).

The most prominent shrine in the holy site is the shrine of Ratu Ayu
Mas Subandar. From an architectural perspective, the physical structure of Ratu Ayu Mas Subandar is similar to the others shrines at Dalem Balingkang temple. It is in the form of a gedong, consisting of three parts, namely the base or bebaturan (legs), pengawak or body, and top (head) or raab (roof). The shrine was constructed from local materials such as solid stones, bricks, woods, and palm fibers as roof coverings. A visitor would realize the building's uniqueness from its installed attributes, decorations and color utilization such as red paint, tedung, bed net, lanterns, bamboo curtain and hiolo, a colossal incense holder.

The shrine of Ratu Ayu Mas Subandar sits inside the main temple on the northeastern side. It is easily recognized from its Kupang nameplate. Kupang is a vocabulary for Uang Kepeng, a holedmetal coin in the period of the Dalem Balingkang kingdom. The Kupang has received a significant function in Balinese society since it was used as dowry for Queen Kang Ching We marriage. Her father, a man, well known by the name I Subandar, gave the Kupang as dowry. Later, King Sri Haji Jaya Pangus issued a decree to request his people use the coin as a complement in the Yadnya ceremony that made the instrument exist up to the moment. In addition, it was said that the coin was requested from Queen Kang's hometown to help the economic situation in the kingdom. ${ }^{13}$

In art, the influence of Chinese culture can be seen from wali dances staged in the annual temple ceremony. The Baris Ngepang Truna dance, the Baris Gede dance, the Baris Jojor dance, the Presi Dance, the Baris Dadap dance and War Dance. The Chinese touch strongly influences the dancer's costumes. From its ornaments, color's vibe, dance properties, choreography, and musical arrangement. ${ }^{15}$ At the society level, Chinese influence can be seen from the architectural material. For instance, almost 75 percent of folk of Pinggan Village incorporates bamboo tiles as their roofs. The tradition to utilize bamboo was believed to be passed from their ancestry. ${ }^{1}$

Acculturation ofBali-China culturecan also be found in communities of Baturiti, Marga, Pupuan, Petang, Carangsari, Gumicik-Sukawati, Blahbatuh-Gianyar, Renon, Sanur, and Menanga. The ChineseBalinese communities commonly reside adjacent to traditional markets since their first man went to Bali as a trader. In addition, they are partly well assimilated by using Balinese names, such as Putu, Made, Nyoman, and Ketut. As well as using Balinese as their mother tongue instead of the Chinese language. At Pabean, Sangsit (Buleleng), Pesanggaran (Denpasar), Abiansemal (Badung), a Confucians Konco are situated side by side with temples. ${ }^{3}$

Likewise, Balinese and Chinese acculturation occurred throughout the island. It can be seen in many aspects of Balinese sociocultural life. Uang Kepeng was a popular transaction instrument during the Bali Mula dynasty $\left(8^{\text {th }}-14^{\text {th }}\right.$ centuries) in the economic field. Today, the Uang Kepeng no longer serves as a transactional instrument. Then, on a ritual level, the Balinese have been using 
incense as a ritual instrument. Moreover, numerous Chinese vocabularies are naturally absorbed in Balinese society, spoken daily by the local folk. Words such as guci (Chinese porcelain), dacin (scale), Çang Apit and Barong were not from the local tongue. In the field of art, Balinese is familiar with the romance-tragedy story of Sampik Ing Tai. Many writers composed Geguritan based on the famous tale from China and recreated it as the theme of the theatre performance Arja. The costume of Barong, the shape, accessories were strongly influenced by a touch of Chinese culture. ${ }^{16}$

\section{CONCLUSION}

The temple of Dalem Balingkang is proof that Bali - china acculturation has existed for centuries on the island. it was a palace for King Sri Haji Jaya Pangus who according to Purana Dalem Balingkang, reigned Bali in 1053 Isaka/1131 AD. However, due to some circumstances, the castle was left abandoned. Then a King from Pejeng, I Dewa Mayun Sudha, reconstructed the palace ruin into a temple to praise the late King and Queen of Dalem Balingkang. King Sri Haji Jaya Pangus's marriage with the daughter of Chinese trader Kang Ching We became an essential momentum of acculturation between Bali and China. As an upperclass citizen, it set a new standard in society. Gradually some foreign habits and customs were absorbed in local daily life. It can be seen in various aspects of their life, from ritual, economic, religion, social, architecture, art and culture. Further, Balinese Chinese culture's acculturation also occurred throughout Bali's region and existed up to the moment.

\section{REFERENCES}

1. Budiana IP, Mudana IW, Arta KS. Pemanfaatan kebudayaan cina pada masa pemerintahan sri haji jayapangus di pura dalem balingkang, di desa pinggan, kintamani, bangli dan potensinya sebagai sumber belajar sejarah lokal di sma. Widya Winayata: Jurnal Pendidikan Sejarah. 2015 Aug 12;3(2)

2. IG Agung. Bali Pada abad XIX. Yogyakarta:Universitas Gajah Mada. 1989.

3. Rachmawati. Balingkang, Akulturasi Tionghoa di Bali, Saat Sang Raja Jatuh Cinta Pada Putri dari China. Kompas[dot]com. 2021. Available at URL: https://denpasar.kompas. com/read/2021/03/14/080800278/balingkangakulturasi-tionghoa-di-bali-saat-sang-rajajatuh-cinta-pada?page $=$ all.

4. Image of Mount Penulisan taken from article IJ Susun 'Mount Penulisan Jungle Trekking'. balitrekkingtour[dot]net. 2017. Available at URL: https://balitrekkingtour.net/mountpenulisan-jungle-trekking/

5. Goris, R. (1954). Prasasti Bali I. Bandung: Masa Baru.

6. IK Riana. Melacak Ihwal Pura Dalem Balingkang. Bali Post. 2007. Available at URL: https://www.babadbali.com/pura/plan/ balingkang.htm

7. Tim Penyusun. Purana Pura Dalem Balingkang. Denpasar : Dinas Kebudayaan Provinsi Bali. 2009.
8. Kusuma IN, Sedyawati E, Bagus IG, Ikram A, Poespowardojo S, Damono SD, Adiwimarta SS. Kakawin usana Bali Mayantaka carita: suntingan teks, terjemahan serta telaah bentuk kakawin dan konsep-konsep kepercayaan.

9. J Triguritno. Sejarah Dibalik Megahnya Pura Dalem Balingkang Bali. Kintamani[dot]id. 2021. Available at URL: https://www.kintamani. id/sejarah-pura-dalem-balingkang-bali/

10. Painting of 'Barong Landung' by I Made Suanda. Borobudur Auction - Jakarta. Available at URL: https://www.mutualart.com/Artwork/ Barong-Landung/23C92E8820B83672

11. Image taken from article 'BARONG LANDUNG: BALINESE LEGEND'. Bali Around. Available at URL: https://www. baliaround.com/barong-landung/

12. IA Indah. 'Ratu Ayu Subandar Shrine. Chinese Element in Balinese temple'. balidaily. 2015. Available at URL: https://balidaily.wordpress. com/2015/11/06/ratu-ayu-subandar-shrineornate-chinese-in-balinese-temple/

13. Admin Disbud. Sejarah Barong Landung. Buleleng Regency Cultural Office Official Website. 2019. Available at URL: https:// disbud.bulelengkab.go.id/informasi/detail/ artikel/sejarah-barong-landung-58

14. Image by ewie_hu's Instagram Post, taken from Article Pura Dalem Balingkang, a Lovely Balinese Hindu Temple with a Chinese Twist. travelingyuk[dot]com. 2019. Available at URL: https://travelingyuk.com/pura-dalembalingkang/188660/

15. TimLiputan. Arsitektur Pura Dalem Balingkang, Salah Satu Daya Tarik Utama Wisatawan Tiongkok. Berita Bali. 2019. Available at URL: https://www.aboutbali.beritabali.com/ $\mathrm{read} / 2019 / 12 / 26 / 201912260013 /$ arsitekturpura-dalem-balingkang-salah-satu-daya-tarikutama-wisatawan-tiongkok-3

16. Puspawati GA, Geria AA. TARI WALI DI PURA DALEM BALINGKANG DESA PINGGAN KECAMATAN KINTAMANI KABUPATEN BANGLI

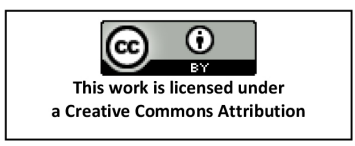

